\title{
Quantification of structural uncertainty in climate data records from GPS radio occultation
}

\author{
A. K. Steiner ${ }^{1,2}$, D. Hunt ${ }^{3}$, S.-P. Ho ${ }^{3}$, G. Kirchengast ${ }^{1}$, A. J. Mannucci ${ }^{4}$, B. Scherllin-Pirscher ${ }^{1,3}$, H. Gleisner ${ }^{5}$, A. von \\ Engeln $^{6}$, T. Schmidt ${ }^{7}$, C. Ao $^{4}$, S. S. Leroy ${ }^{8}$, E. R. Kursinski ${ }^{9}$, U. Foelsche ${ }^{1}$, M. Gorbunov ${ }^{10}$, S. Heise ${ }^{7}$, Y.-H. Kuo ${ }^{3}$, K.

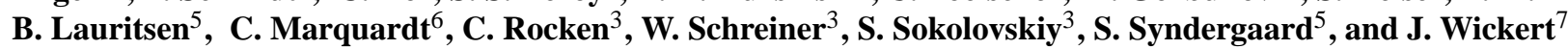 \\ ${ }^{1}$ Wegener Center for Climate and Global Change (WEGC) and Institute for Geophysics, Astrophysics, and \\ Meteorology/Institute of Physics (IGAM/IP), University of Graz, Graz, Austria \\ ${ }^{2}$ Institute of Remote Sensing and Photogrammetry, Graz University of Technology, Graz, Austria \\ ${ }^{3}$ COSMIC Project Office, University Corporation for Atmospheric Research (UCAR), Boulder, CO, USA \\ ${ }^{4}$ Jet Propulsion Laboratory (JPL), California Institute of Technology, Pasadena, CA, USA \\ ${ }^{5}$ Danish Meteorological Institute (DMI), Copenhagen, Denmark \\ ${ }^{6}$ EUMETSAT (EUM), Darmstadt, Germany \\ ${ }^{7}$ Dept. Geodesy and Remote Sensing, German Research Centre for Geosciences (GFZ), Potsdam, Germany \\ ${ }^{8}$ School of Engineering and Applied Sciences, Harvard University, Cambridge, MA, USA \\ ${ }^{9}$ Institute of Atmospheric Physics, University of Arizona, Tucson, AZ, USA \\ ${ }^{10}$ Institute of Atmospheric Physics, Russian Academy of Sciences, Moscow, Russian
}

Correspondence to: A. K. Steiner (andi.steiner@uni-graz.at)

Received: 27 July 2012 - Published in Atmos. Chem. Phys. Discuss.: 12 October 2012

Revised: 21 December 2012 - Accepted: 18 January 2013 - Published: 6 February 2013

\begin{abstract}
Global Positioning System (GPS) radio occultation (RO) has provided continuous observations of the Earth's atmosphere since 2001 with global coverage, allweather capability, and high accuracy and vertical resolution in the upper troposphere and lower stratosphere (UTLS). Precise time measurements enable long-term stability but careful processing is needed. Here we provide climate-oriented atmospheric scientists with multicenter-based results on the long-term stability of RO climatological fields for trend studies. We quantify the structural uncertainty of atmospheric trends estimated from the RO record, which arises from current processing schemes of six international RO processing centers, DMI Copenhagen, EUM Darmstadt, GFZ Potsdam, JPL Pasadena, UCAR Boulder, and WEGC Graz. Monthlymean zonal-mean fields of bending angle, refractivity, dry pressure, dry geopotential height, and dry temperature from the CHAMP mission are compared for September 2001 to September 2008. We find that structural uncertainty is lowest in the tropics and mid-latitudes $\left(50^{\circ} \mathrm{S}\right.$ to $\left.50^{\circ} \mathrm{N}\right)$ from $8 \mathrm{~km}$ to $25 \mathrm{~km}$ for all inspected $\mathrm{RO}$ variables. In this region, the structural uncertainty in trends over $7 \mathrm{yr}$ is $<0.03 \%$ for bend-
\end{abstract}

ing angle, refractivity, and pressure, $<3 \mathrm{~m}$ for geopotential height of pressure levels, and $<0.06 \mathrm{~K}$ for temperature; low enough for detecting a climate change signal within about a decade. Larger structural uncertainty above about $25 \mathrm{~km}$ and at high latitudes is attributable to differences in the processing schemes, which undergo continuous improvements. Though current use of RO for reliable climate trend assessment is bound to $50^{\circ} \mathrm{S}$ to $50^{\circ} \mathrm{N}$, our results show that quality, consistency, and reproducibility are favorable in the UTLS for the establishment of a climate benchmark record.

\section{Introduction}

The need for accurate long-term observations of the Earth's atmosphere for climate monitoring is commonly agreed upon and the scientific community undertakes strong efforts towards achieving this goal (Karl et al., 2006; Trenberth et al., 2007). Requirements for the generation of climate data sets (Ohring, 2007; GCOS, 2010) comprise long-term stability, reproducibility, global coverage, accuracy, resolution in 
space and time, description and validation of the products. Fundamental climate data records are defined by the Global Climate Observing System programme (GCOS, 2010) as homogeneous records derived from a series of instruments with sufficient calibration and quality control. Observation requirements are defined for essential climate variables (ECVs) such as upper air temperature, including for this variable a resolution of $500 \mathrm{~km}$ horizontally, $0.5 \mathrm{~km}$ vertically in the upper troposphere, $1.5 \mathrm{~km}$ vertically in the lower stratosphere, and a root mean square (RMS) accuracy of $<0.5 \mathrm{~K}$.

Upper-air climate records from conventional observations such as weather balloons and microwave soundings currently fail to fulfill GCOS requirements (Immler et al., 2010). These observations were primarily intended for short-term weather forecasting and not for climate monitoring, the latter demanding accurate and long-term stable measurements. A substantial degree of uncertainty arises from changes in instrumentation and observation practice over time. Demanding homogenization and intercalibration procedures are required for the construction of a climate record and uncertainties in the trend rates and their vertical structure remain large in the upper troposphere and stratosphere (e.g. Randel et al., 2009; Thorne et al., 2011).

For a specific observational record, structural uncertainty arises due to different choices in processing and methodological approaches for constructing a data set from the same raw data (Thorne et al., 2005). Structural uncertainty for upperair records decreases by increasing the number of independent observational data sets. Thus, multiple independent efforts should be undertaken to create climate records.

Global Positioning System (GPS) radio occultation (RO) is a relatively new and promising data source. It has provided continuous observations of the Earth's atmosphere since 2001 with global coverage, all-weather capability, and high accuracy and vertical resolution in the upper troposphere and lower stratosphere (UTLS) (Kursinski et al., 1997). RO errors are well characterized from observational errors of individual profiles to the full error description of climatological fields (Scherllin-Pirscher et al., 2011a, b). The benefits of RO in atmospheric research have already been demonstrated by a range of studies as reviewed by Anthes (2011). The utility of RO for climate monitoring and trend detection was recently reviewed by Steiner et al. (2011).

One important property of RO is its long-term stability due to precise time measurements traceable to the international time standard. Data from different RO missions can be combined without adjustments and inter-calibration (Hajj et al., 2004; Schreiner et al., 2007) to a consistent climate record (Foelsche et al., 2011). This is regarded as one property of a climate benchmark data type (Leroy et al., 2006a; Mannucci et al., 2006; Ohring, 2007). Another property is that climate trends are nominally independent of processing schemes. Therefore, the quantification of structural uncertainty in the record arising from different processing schemes is essential. In this context an international collaboration on the intercom- parison of multi-year RO data records was started in 2007 for a systematic assessment of the accuracy and quality of data from different $\mathrm{RO}$ processing centers. The aim is to validate RO as a climate benchmark by demonstrating that trends in $\mathrm{RO}$ data products are essentially independent of retrieval center. A first intercomparison showed low structural uncertainty for 5-yr refractivity climatological fields provided by four centers (Ho et al., 2009).

As a further advancement we recently extended the intercomparison to newest data sets provided by six international processing centers for the common RO record of the CHAllenging Minisatellite Payload for geoscientific research (CHAMP) satellite from September 2001 to September 2008. The centers provided atmospheric products as individual profiles and gridded climatological fields. Using basically the same raw measurements as input, different processing schemes provide different numbers and distributions of retrieved profiles that flow into climatological fields. Intentionally disregarding these differences in a first step, Ho et al. (2012) investigated the reproducibility of RO individual profiles based on a profile-by-profile matched data set. Using such synthetic subsets of profiles from each center's products, they found high reproducibility consistent with the previous refractivity results of Ho et al. (2009).

In this study we account for all differences and focus directly on RO climatological fields, in order to quantify their long-term stability and uncertainty regarding atmospheric trends. This is especially of interest for climate-oriented scientists who might download and use such RO climatological fields for their research. We quantify the structural uncertainty of the climate records for the full set of atmospheric RO variables including bending angle, refractivity, dry pressure, dry geopotential height, and dry temperature in the UTLS. For more information on the difference between "dry" RO parameters and actual parameters, which is negligible above about $8 \mathrm{~km}$ to $12 \mathrm{~km}$ altitude, see ScherllinPirscher et al. (2011a).

An overview of RO data and on the processing is given in Sect. 2. The study setup and method is described in Sect. 3. Results are discussed in Sect. 4 and conclusions are drawn in Sect. 5 .

\section{RO data and processing description}

RO data products for this study are provided by the following processing centers: Danish Meteorological Institute (DMI) Copenhagen, Denmark; EUMETSAT (EUM) Darmstadt, Germany; German Research Centre for Geosciences (GFZ) Potsdam, Germany; Jet Propulsion Laboratory (JPL) Pasadena, CA, USA; University Corporation for Atmospheric Research (UCAR) Boulder, CO, USA; and Wegener Center/University of Graz (WEGC), Graz, Austria. For basic understanding of the retrieval process, we here briefly 
Table 1. Overview on processing chains at DMI, EUM, GFZ, JPL, UCAR, and WEGC (after Ho et al., 2012; Table 1 therein).

\begin{tabular}{|c|c|c|}
\hline $\begin{array}{l}\text { URL/ } \\
\text { Processing step }\end{array}$ & Center & Implementations of each center \\
\hline URL & $\begin{array}{l}\text { DMI } \\
\text { EUM } \\
\text { GFZ } \\
\text { JPL } \\
\text { UCAR } \\
\text { WEGC }\end{array}$ & $\begin{array}{l}\text { http://www.romsaf.org } \\
\text { http://www.eumetsat.int } \\
\text { http://isdc.gfz-potsdam.de } \\
\text { http://genesis.jpl.nasa.gov } \\
\text { http://www.cosmic.ucar.edu } \\
\text { http://www.wegcenter.at/globclim }\end{array}$ \\
\hline \multirow{6}{*}{$\begin{array}{l}\text { Processing } \\
\text { version and } \\
\text { POD phase } \\
\text { and orbit data } \\
\text { version }\end{array}$} & DMI & $\begin{array}{l}\text { Version OCC_20.6.688; UCAR CDAAC orbit and phase data used } \\
\text { (v2009.2650). }\end{array}$ \\
\hline & EUM & $\begin{array}{l}\text { Version YAROS 0.1(Beta) - ROTrend_5.1_Prof; } \\
\text { UCAR CDAAC orbit and phase data used (v2009.2650). }\end{array}$ \\
\hline & GFZ & $\begin{array}{l}\text { Version POCS ATM vers.006; POD with EPOS-OC software (König et al., } \\
\text { 2006); Excess phase: Single differencing, reference link smoothing. }\end{array}$ \\
\hline & JPL & $\begin{array}{l}\text { Version v2fo_10Kp1N; POD: reduced-dynamic strategy using GIPSY software } \\
\text { (Bertiger et al., 1994); Excess phase: Double differencing. }\end{array}$ \\
\hline & UCAR & $\begin{array}{l}\text { Version 2009.2650; POD with Bernese v5.0 software (Dach et al., 2007); } \\
\text { Excess phase: Single differencing, reference link smoothing (Schreiner et al., } \\
\text { 2010). }\end{array}$ \\
\hline & WEGC & Version OPSv5.4; UCAR orbit and phase data used (v2009.2650). \\
\hline \multirow[t]{6}{*}{$\begin{array}{l}\text { Bending angle } \\
\text { calculation }\end{array}$} & DMI & $\begin{array}{l}\text { Canonical Transform (CT2) inversion (Gorbunov and Lauritsen, 2004) }<25 \mathrm{~km} \text {, } \\
\text { combined with Geometric Optics (GO) above. }\end{array}$ \\
\hline & EUM & GO used for bending angles at all heights. \\
\hline & GFZ & Full Spectrum Inversion (FSI) < 15 km (Jensen et al., 2003); GO above. \\
\hline & JPL & Canonical transform (CT) after Gorbunov (2002) applied to L1 < $30 \mathrm{~km}$. \\
\hline & UCAR & FSI (Jensen et al., 2003) applied to L1 below dynamic L2 QC height; GO above. \\
\hline & WEGC & GO used for L1 and L2 bending angles at all heights. \\
\hline \multirow[t]{7}{*}{$\begin{array}{l}\text { Ionospheric } \\
\text { correction }\end{array}$} & & $\begin{array}{l}\text { Linear combination of L1 and L2 bending angles (Vorob'ev and Krasil'ni- } \\
\text { kova, 1994) }\end{array}$ \\
\hline & DMI & $\begin{array}{l}\text { Optimal linar comb. (Gorbunov, 2002); Ionospheric correction term extrapola- } \\
\text { tion below dynamic L2 QC height }\end{array}$ \\
\hline & EUM & Linear combination. \\
\hline & GFZ & Linear combination. \\
\hline & JPL & $\begin{array}{l}\text { Linear combination; Iono. corr. term extrapol. when L2 signal-to noise ratio } \\
<30 \text {. }\end{array}$ \\
\hline & UCAR & $\begin{array}{l}\text { Linear combination with optimal smoothing of L4 bending angle (Sokolovskiy } \\
\text { et al., 2009); Ionospheric correction term extrapolation < dynamic L2 QC } \\
\text { height. }\end{array}$ \\
\hline & WEGC & Linear combination; Ionospheric correction term extrapolation $<15 \mathrm{~km}$. \\
\hline \multirow[t]{5}{*}{$\begin{array}{l}\text { Initialization of } \\
\text { bending angles }\end{array}$} & DMI & $\begin{array}{l}\text { Optimization with dynamic estimation of observation errors (Gorbunov, 2002), } \\
\text { using a two-parameter fit of background (MSISE-90) to data }>40 \mathrm{~km} \text { combined } \\
\text { with a global background search (Lauritsen et al., 2011); background error fixed } \\
\text { at } 50 \% \text {. }\end{array}$ \\
\hline & GFZ & $\begin{array}{l}\text { Optimization after Sokolovskiy and Hunt (1996) with MSISE-90 }(>40 \mathrm{~km}) \text {, } \\
\text { obs. error variance estimate in } 60-70 \mathrm{~km} \text {, divided by } 4 \text { to increase weight of } \\
\text { RO data. }\end{array}$ \\
\hline & JPL & $\begin{array}{l}\text { Exponential extrapolation based on least-squares fit of measurements at } 40 \text { - } \\
50 \mathrm{~km} \text {. }\end{array}$ \\
\hline & UCAR & $\begin{array}{l}\text { Optimization after Sokolovskiy and Hunt (1996) with fitting background profile } \\
\text { (NCAR climatology extrapolated to } 150 \mathrm{~km} \text { ), dynamic estimation of the top fit } \\
\text { height, background and obs. errors (Lohmann, 2005). }\end{array}$ \\
\hline & WEGC & $\begin{array}{l}\text { Statistical optimization }>30 \mathrm{~km} \text { with ECMWF short-range forecasts and above } \\
\text { MSISE-90 to } 120 \mathrm{~km} \text { (Healy, 2001), dynamic estimation of obs. errors and in- } \\
\text { verse covariance weighting (Gobiet and Kirchengast, 2004; Gobiet et al., 2007). }\end{array}$ \\
\hline
\end{tabular}


Table 1. Continued.

\begin{tabular}{|c|c|c|}
\hline $\begin{array}{l}\text { URL/ } \\
\text { Processing step }\end{array}$ & Center & Implementations of each center \\
\hline \multirow[t]{5}{*}{$\begin{array}{l}\text { Refractivity } \\
\text { retrieval }\end{array}$} & DMI & $\begin{array}{l}\text { Abel inversion (Fjeldbo et al., 1971) of optimized bending angle profile. } \\
\text { Numerical calculation of the Abel integral from each height to } 150 \mathrm{~km} \text {. }\end{array}$ \\
\hline & GFZ & Abel inversion starts at $150 \mathrm{~km}$. \\
\hline & JPL & Abel inversion starts at $120 \mathrm{~km}$. \\
\hline & UCAR & $\begin{array}{l}\text { Abel inversion below } 150 \mathrm{~km} \text { by applying the finite-difference representation } \\
\text { (Sokolovskiy et al., 2005). }\end{array}$ \\
\hline & WEGC & $\begin{array}{l}\text { Numerical integration over bending angle (Simpson's trapezoidal rule) from } \\
\text { each height (impact par.) to } 120 \mathrm{~km} \text {. Impact parameter to height conversion } \\
\text { with radius of curvature at mean tangent point (TP) location (Syndergaard, } \\
\text { 1998); Sinc-windowed Blackman filter on refractivity ( }<1 \mathrm{~km} \text { moving average, } \\
\text { for resolution-conserving filtering of residual numerical processing noise). }\end{array}$ \\
\hline \multirow[t]{7}{*}{ Dry air retrieval } & & $\begin{array}{l}\text { Refractivity }(N) \text { is directly proportional to air density (applying ideal gas equa- } \\
\text { tion). }\end{array}$ \\
\hline & DMI & $\begin{array}{l}\text { Pressure downward integration of the hydrostatic equation from } 150 \mathrm{~km} \text { (bound- } \\
\text { ary conditions determined from the refractivity and its gradient at the top); Dry } \\
\text { geopotential height relative to EGM- } 96 \text { geoid; }\end{array}$ \\
\hline & GFZ & $\begin{array}{l}\text { Pressure retrieval is initialized at } 100 \mathrm{~km} \text { with MSISE- } 90 \text {. Pressure down- } \\
\text { ward integration using hydrostatic equation; Dry geopotential height relative } \\
\text { to EGM-96. }\end{array}$ \\
\hline & JPL & $\begin{array}{l}\text { Pressure integration using hydrostatic equation starting at } 40 \mathrm{~km} \text { initialized with } \\
\text { ECMWF temperature. Dry geopotential height relative to JGM-3. }\end{array}$ \\
\hline & UCAR & $\begin{array}{l}\text { Pressure integration using hydrostatic equation, initialized at } 150 \mathrm{~km} \text { by setting } \\
\text { pressure and temperature to zero. }\end{array}$ \\
\hline & WEGC & $\begin{array}{l}\text { Hydrostatic integral initialization at } 120 \mathrm{~km} \text {, pressure = pressure(MSISE-90); } \\
\text { no initialization below } 120 \mathrm{~km} \text { (downward integration); Dry geopotential height } \\
\text { relative to EGM-96; Same filtering on dry temperature as for refractivity filter- } \\
\text { ing. }\end{array}$ \\
\hline & All centers & $\begin{array}{l}\text { Dry temperature }(T) \text { is obtained using the Smith-Weintraub formula for dry air } \\
\text { (Smith and Weintraub, 1953) and the equation of state (ideal gas). }\end{array}$ \\
\hline \multirow{9}{*}{$\begin{array}{l}\text { Quality control } \\
\text { (QC) }\end{array}$} & DMI & QC of L2 quality from impact parameters (noise); \\
\hline & & QC of bending angle using model from iono. corr.; \\
\hline & & QC of $N$ using ECMWF analyses: reject if $\Delta N>10 \%$ in $10-35 \mathrm{~km}$ \\
\hline & EUM & QC based on robust statistics (Hoaglin et al., 1983). \\
\hline & GFZ & QC of forward differences of excess phases; \\
\hline & & QC of $N$ using MSIS-90: reject if $\Delta N>22.5 \%$ in $8-31 \mathrm{~km}$ \\
\hline & JPL & $\begin{array}{l}\text { QC of Doppler shift }<6 \mathrm{~km} \text {; QC of } N, T<40 \mathrm{~km} \text { to ECMWF analyses: reject } \\
\text { if } \Delta N>10 \% \text { and } \Delta T>10 \mathrm{~K} \text { below } 30 \mathrm{~km} .\end{array}$ \\
\hline & UCAR & $\begin{array}{l}\text { QC of raw L1 Doppler (truncation); QC of L2 Doppler (reject if dynamic QC } \\
\text { height }>20 \mathrm{~km} \text { ); QC of bending angle (reject if top fit height }<40 \mathrm{~km} \text { ); } \\
\text { QC of } N \text { using climatology: reject if } \Delta N>50 \% \text {. }\end{array}$ \\
\hline & WEGC & $\begin{array}{l}\text { QC of excess phases and bending angles; QC of } N, T \text { using ECMWF analyses: } \\
\text { reject if } \Delta N>10 \% \text { in } 5-35 \mathrm{~km} \text { and/or } \Delta T>20 \mathrm{~K} \text { in } 8-25 \mathrm{~km} \text {. }\end{array}$ \\
\hline \multirow[t]{5}{*}{$\begin{array}{l}\text { Reference frame } \\
\text { vertical coordinate }\end{array}$} & DMI/EUM & $\begin{array}{l}\text { Earth figure: WGS- } 84 \text { ellipsoid; Vertical coordinate: mean-sea-level (m.s.l.) al- } \\
\text { titude; Conversion of (ellipsoidal) height to m.s.l. altitude (at mean TP location) } \\
\text { via EGM- } 96 \text { geoid smoothed to } 1^{\circ} \times 1^{\circ} \text { resolution. }\end{array}$ \\
\hline & GFZ & $\begin{array}{l}\text { Earth figure: WGS-84 ellipsoid; Vertical coordinate: } \mathrm{m} . \mathrm{s} .1 \text {. altitude; Conversion } \\
\text { of (ellipsoidal) height to m.s.1. altitude (at location of } 20 \mathrm{~km} \text { impact altitude) via } \\
\text { EGM-96 geoid smoothed to } 1^{\circ} \times 1^{\circ} \text { resolution. }\end{array}$ \\
\hline & JPL & $\begin{array}{l}\text { Earth figure: IERS Standards } 1989 \text { elliposid; Vertical coordinate: m.s.l. alti- } \\
\text { tude computed using the JGM3/OSU91A geoid trunc. at spherical harmonic } \\
\text { degree } 36 \text {. }\end{array}$ \\
\hline & UCAR & $\begin{array}{l}\text { Earth figure: ITRF-93 ellipsoid; Vertical coordinate: m.s.l. altitude; Conversion } \\
\text { of height over ellipsoid to m.s.l. altitude at the occultation point (location of GO } \\
\text { estimated TP for } 500 \mathrm{~m} \text { excess phase) via JGM- } 2 \text { geoid at } 0.125^{\circ} \text { resolution. }\end{array}$ \\
\hline & WEGC & $\begin{array}{l}\text { Earth figure: WGS-84 ellipsoid; Vertical coordinate: m.s.l. altitude; Conversion } \\
\text { of (ellipsoidal) height to m.s.l. altitude (at mean TP location) via EGM-96 geoid } \\
\text { smoothed to } 2^{\circ} \times 2^{\circ} \text { resolution. }\end{array}$ \\
\hline
\end{tabular}


summarize first the retrieval steps from raw measurements to atmospheric parameters.

RO measurements are based on GPS signals, which are received on a Low Earth Orbit (LEO) satellite. GPS satellites transmit dual-frequency signals in the microwave range at wavelengths of $0.19 \mathrm{~m}$ (L1 signal) and $0.24 \mathrm{~m}$ (L2 signal), which are virtually unaffected by clouds and aerosols. The radio signals are refracted and retarded during their propagation through the atmospheric refractivity field. Vertical scanning of the atmosphere is provided through movement of the satellites. An occultation event occurs if a GPS satellite sets behind (or rises from behind) the horizon. Its signals are then occulted by the Earth's limb from the viewpoint of the receiver. The basic measurement is the signal phase anchored by precise timing with atomic clocks. It is proportional to the optical path length between the transmitter and the receiver. Potential clock errors of GPS or LEO satellites are removed by differencing methods using an additional nonocculted GPS satellite as reference (single-differencing) and by relating the measurement to even more stable oscillators on the ground (double-differencing). In case there are ultrastable clocks aboard LEO satellites, no differencing is needed (zero-differencing).

Precise orbit determination (POD) provides orbit and velocity information which is used to compute the kinematic Doppler shift (due to the relative motion of the GPS and LEO satellites). It is removed and the atmospheric Doppler shift is then converted to bending angle when geometric optics is applied. Wave optics methods use the phase and amplitude information for the retrieval of the bending angle, which basically represents the cumulative signal refraction due to atmospheric density gradients. The contribution of the ionosphere can be removed since two GPS signals at different wavelengths are used. The so-called ionospheric correction is performed by differencing these dual-frequency GPS signals, typically through linear combination of bending angles (Vorobév and Krasil'nikova, 1994).

The bending angle decreases exponentially with altitude but the measurement noise stays relatively constant in the stratosphere, which leads to an exponential decrease in signal-to-noise ratio with altitude. In order to calculate refractivity, an initialization of bending angles with a priori information is performed at high altitudes to reduce the effect of error propagation downward. These optimized bending angle profiles are converted to refractivity profiles via an Abel transform (Fjeldbo et al., 1971). Density, pressure, and temperature are retrieved for dry air conditions in the UTLS by using the refractivity equation (Smith and Weintraub, 1953), the hydrostatic equation, and the equation of state. Geopotential height is computed by integrating the latitude- and height-dependent acceleration of gravity over the RO derived altitude, divided by the standard acceleration of gravity. The retrieved variables from optimized bending angle to temperature are not traceable to an SI standard but these variables are derived from timing measurements based on ultra-stable clocks that ensure long-term stability and reproducibility. Quality control mechanisms are applied that affect the final number of provided RO profiles for each center. On average the CHAMP mission provided about 4500 high quality profiles per month.

A general description of the $\mathrm{RO}$ processing chain is given by, e.g. Kursinski et al. (1997) and Hajj et al. (2002). The main characteristics of RO are reviewed by Steiner et al. (2011). An overview on the relevant processing schemes of this study as implemented by each center is given in Table 1. It includes information on processing versions, bending angle calculation, ionospheric correction, initialization of bending angles, refractivity retrieval, dry air retrieval, and quality control. A more detailed description of the centers' processing schemes is contained in Ho et al. (2012).

\section{Study setup and method}

We investigate climatological fields of bending angle, refractivity, dry pressure, dry geopotential height, and dry temperature. Each center provided RO profiles of these variables from the CHAMP satellite (Wickert et al., 2004) for the common period September 2001 to September 2008, except EUM provided only bending angle. The profiles are averaged into monthly-mean zonal-mean climatological fields, using $5^{\circ}$-latitude bins, for the UTLS altitude range of $8 \mathrm{~km}$ to $30 \mathrm{~km}$ at a $200 \mathrm{~m}$ vertical grid. The reference frame for the vertical coordinate is the geoid. Bending angle is given as a function of impact altitude, i.e. impact parameter minus radius of curvature minus the undulation of the geoid. The impact parameter is defined as the perpendicular distance between the center of local curvature (which is close to the Earth's center) and the ray path from the GPS satellite (e.g. Kursinski et al., 1997). Refractivity, pressure, and temperature are given as function of mean-sea-level (m.s.l.) altitude, i.e. geometric height above the geoid. In order to set geopotential height into meteorological context we relate it to pressure levels. We express it as a function of pressure in form of a "pressure altitude". The pressure altitude is defined as $z_{p}[\mathrm{~m}]=(7000 \mathrm{~m}) \cdot \ln (1013.25 \mathrm{hPa} / p[\mathrm{hPa}])$.

The intercomparison is performed for the full monthly $5^{\circ}$-bin zonal-mean fields as well as for larger-bin zonal means and altitude layers. The larger domains were defined during the course of work based on latitude and altitude regions, where the compared RO data show similar structural uncertainty characteristics. The inspected regions comprise the tropics $\left(20^{\circ} \mathrm{N}-20^{\circ} \mathrm{S}\right)$, the northern/southern mid-latitudes (NML/SML; $20^{\circ} \mathrm{N} / \mathrm{S}-50^{\circ} \mathrm{N} / \mathrm{S}$ ), the northern/southern high-latitudes (NHL/SHL; $50^{\circ} \mathrm{N} / \mathrm{S}-90^{\circ} \mathrm{N} / \mathrm{S}$ ), and a large-scale focus region $\left(50^{\circ} \mathrm{N}-50^{\circ} \mathrm{S}\right)$ for the altitude layers $8 \mathrm{~km}-12 \mathrm{~km}, 12 \mathrm{~km}-16 \mathrm{~km}, 16 \mathrm{~km}-25 \mathrm{~km}, 25 \mathrm{~km}-$ $30 \mathrm{~km}$, and $8 \mathrm{~km}-25 \mathrm{~km}$.

We account for sampling error which stems from discrete sampling in space and time, since the centers provide 
slightly different numbers of high quality profiles. We use the European Centre for Medium-Range Weather Forecasts (ECMWF) reanalysis ERA-Interim (Poli et al., 2010; Dee et al., 2011) as a reference field for sampling error estimation (Foelsche et al., 2008). We compute the sampling error for each atmospheric parameter except bending angle and subtract it from the RO climatologies (Scherllin-Pirscher et al., 2011a). (Bending angle requires a more complex forward model that depends on a different altitude coordinate, impact altitude; such a forward model is not yet suitably available for this study). We note that it is common practice to account for the sampling error, either using data (Foelsche et al., 2008) or model estimates (Scherllin-Pirscher et al., 2011a). All subsequent computations are performed with and without the sampling error subtracted from the climatologies.

Anomaly time series are computed by removing the mean annual cycle of the inspected period from the data of each center (7-yr mean). Anomaly difference time series are then computed by subtracting the all-center mean (mean of all centers) from the anomaly time series of each center. Fractional (percentage) anomaly difference time series are obtained for atmospheric parameters which decrease exponentially with altitude (i.e. bending angle, refractivity, and pressure).

In the following, to have the methodology clearly set, explicit equations are provided for the computations performed for each atmospheric parameter $(X)$ of each center (c) given at monthly resolution $(t)$ for latitude bands $(\phi)$ and altitude levels (z), i.e. 5 parameters, 6 centers, 85 months, 36 latitude bands and 110 altitude levels as well as 5 large latitude zones at 4 altitude layers.

First, the all-center mean climatology as function of latitude, altitude, and time, is computed via Eq. (1):

$\bar{X}^{\text {all }}\left(\phi_{i}, z_{j}, t_{k}\right)=\frac{1}{n_{\text {center }}} \sum_{l=1}^{l=n_{\text {center }}} X\left(c_{l}, \phi_{i}, z_{j}, t_{k}\right)$.

The mean difference of each center (c) to the all-center mean averaged over September 2001 to September 2008 (see Fig. 1) is computed after Eq. (2),

$\overline{\Delta X}^{01-08}\left(c_{l}, \phi_{i}, z_{j}\right)=\frac{1}{n_{\text {time }}} \sum_{k=1}^{k=n_{\text {time }}}\left[X\left(c_{l}, \phi_{i}, z_{j}, t_{k}\right)-\bar{X}^{\text {all }}\left(\phi_{i}, z_{j}, t_{k}\right)\right]$,

and the mean fractional difference of each center to the allcenter mean averaged over September 2001 to September 2008 (see Fig. 1) is computed after Eq. (3),

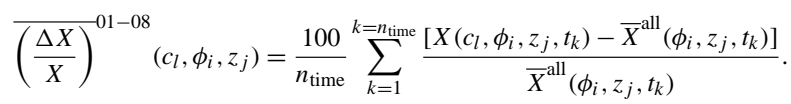

The mean annual cycle of each center as a function of latitude, altitude, and month is computed following Eq. (4):

$\bar{X}^{\text {AnnCycle }}\left(c_{l}, \phi_{i}, z_{j}, t_{k^{\prime}}\right)=\frac{1}{n_{\mathrm{yr}}} \sum_{k^{\prime \prime}=1}^{k^{\prime \prime}=n_{\mathrm{yr}}} X\left(c_{l}, \phi_{i}, z_{j}, t_{k^{\prime \prime}}\right)$.
It is then subtracted according to Eq. (5) to gain deseasonalized anomalies of each center:

$$
\begin{aligned}
\Delta X^{\text {DeseasAnom }}\left(c_{l}, \phi_{i}, z_{j}, t_{k}\right)= & X\left(c_{l}, \phi_{i}, z_{j}, t_{k}\right) \\
& -\bar{X}^{\text {AnnCycle }}\left(c_{l}, \phi_{i}, z_{j}, t_{k \text { mod } 12}\right) .
\end{aligned}
$$

The all-center mean de-seasonalized anomaly as function of latitude, altitude, and time is computed following Eq. (6):

$$
\begin{aligned}
\Delta X^{\text {AllDeseasAnom }}\left(\phi_{i}, z_{j}, t_{k}\right)= & \frac{1}{n_{\text {center }}} \\
& \sum_{l=1}^{l=n_{\text {center }}} \Delta X^{\text {DeseasAnom }}\left(c_{l}, \phi_{i}, z_{j}, t_{k}\right) .(6)
\end{aligned}
$$

Subtraction of the all-center mean from the de-seasonalized anomalies of each center leads to the de-seasonalized anomaly difference time series (Fig. 3) of each center via Eq. (7),

$$
\begin{aligned}
\Delta X^{\text {DeseasAnomDiff }}\left(c_{l}, \phi_{i}, z_{j}, t_{k}\right)= & \Delta X^{\text {DeseasAnom }}\left(c_{l}, \phi_{i}, z_{j}, t_{k}\right) \\
& -\overline{\Delta X}^{\text {AllDeseasAnom }}\left(\phi_{i}, z_{j}, t_{k}\right),
\end{aligned}
$$

and to de-seasonalized fractional anomaly difference time series (Fig. 2) of each center via Eq. (8),

$$
\begin{aligned}
\frac{\Delta X^{\text {DeseasFracAnomDiff }}\left(c_{l}, \phi_{i}, z_{j}, t_{k}\right)}{X} & \\
& 100 \cdot \frac{\Delta X^{\text {DeseasAnomDiff }}\left(c_{l}, \phi_{i}, z_{j}, t_{k}\right)}{\overline{\Delta X}^{\text {AllDeseasAnom }}\left(\phi_{i}, z_{j}, t_{k}\right)} .
\end{aligned}
$$

The purpose of differencing is to remove the climate variability which is common to the data sets and to assess remaining deviations that may be due to different processing methods. Trends in the anomaly difference time series are computed using a linear fit. The spread of anomaly difference trends and finally the standard deviation of the all-center mean trend are used as an estimate of the structural uncertainty of RO records (Wigley, 2006). We note that we do not analyze climatological trends but the uncertainty in trends from RO data with regard to different processing implementations.

\section{Results and discussion}

\subsection{Mean anomaly differences}

Based on the $5^{\circ}$-zonal-mean climatologies with $200 \mathrm{~m}$ vertical spacing from $8 \mathrm{~km}$ to $30 \mathrm{~km}$ altitude, mean anomaly differences ("raw" climatologies including sampling error and annual cycle, anomalies with respect to the all-center mean) are averaged over September 2001 to September 2008 (see Eq. 2). Figure 1 shows the mean anomaly differences for all atmospheric variables from bending angle to temperature. Mean bending angle, as the more basic RO variable, shows more fluctuations in anomaly differences but essentially the same behavior as refractivity. The mean differences in bending angle are within $\pm 0.1 \%$ in most regions. Larger differences occur below about $10 \mathrm{~km}$ and at high latitudes. Refractivity, the variable proportional to atmospheric density, shows 

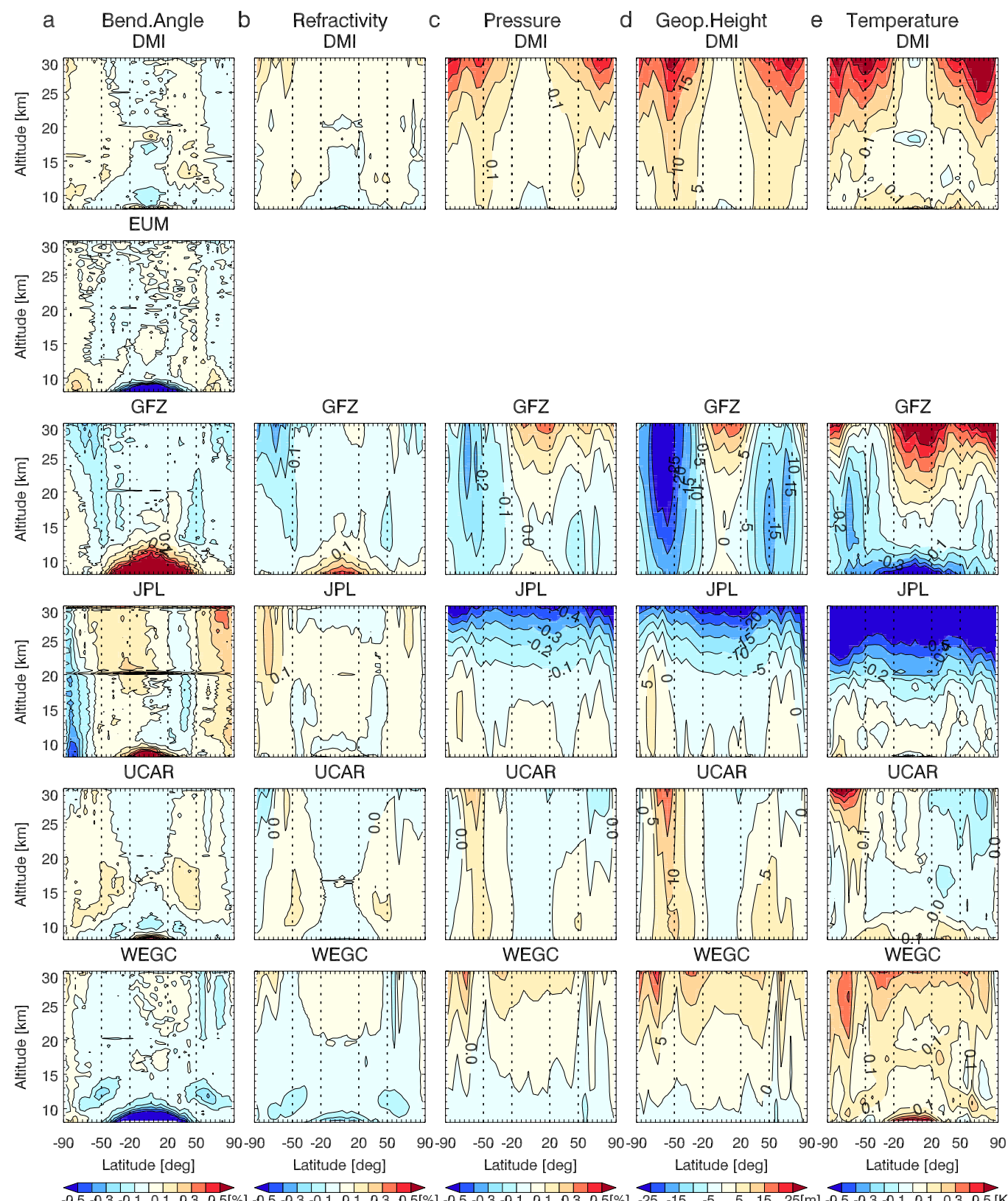

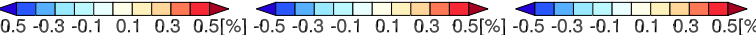

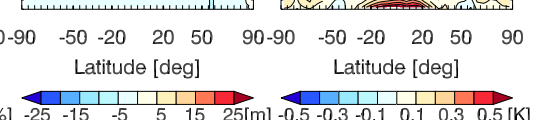

Fig. 1. Mean difference of each center (top to bottom; DMI, EUM, GFZ, JPL, UCAR, WEGC) to the all-center mean for the period September 2001 to September 2008, shown for (a) bending angle, (b) refractivity, (c) pressure, (d) geopotential height, and (e) temperature.

mean differences within $\pm 0.1 \%$ in most regions. At southern high latitudes above about $20 \mathrm{~km}$ and at low latitudes below $10 \mathrm{~km}$ some centers show refractivity differences up to $\pm 0.3 \%$. The other parameters show a smoother behavior due to integration procedures in the retrieval. Mean pressure differences are within $\pm 0.1 \%$ and mean geopotential height differences are $5 \mathrm{~m}$ to $10 \mathrm{~m}$ below about $20 \mathrm{~km}$ altitude, increasing up to $\pm 0.4 \%$ for pressure and to $\sim 25 \mathrm{~m}$ for geopotential height at $30 \mathrm{~km}$. Mean temperature differences are about $\pm 0.1 \mathrm{~K}$ below about $20 \mathrm{~km}$ increasing to about $0.5 \mathrm{~K}$ (and larger for some centers) at $30 \mathrm{~km}$ altitude.

Overall, Fig. 1 demonstrates that certain latitude and altitude ranges show similar structural uncertainty behavior. The more derived the $\mathrm{RO}$ variables, the lower is the altitude where larger differences occur. 

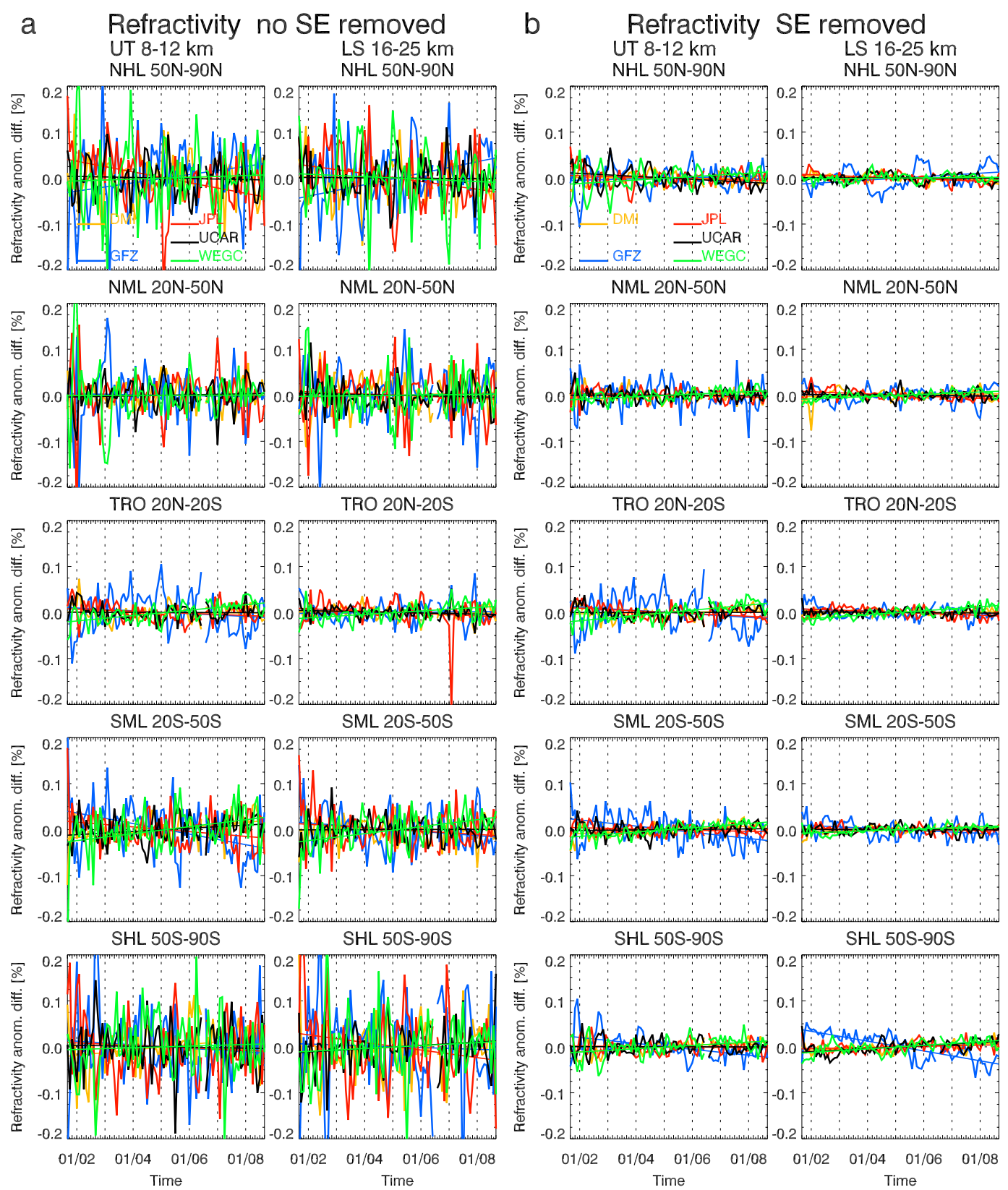

Fig. 2. De-seasonalized anomaly difference time series and trends of (a) refractivity and of (b) refractivity where sampling error was subtracted, shown for the (left) UT and (right) LS for (top to bottom) five zonal regions.

\subsection{De-seasonalized anomaly difference time series and trends}

De-seasonalized anomaly difference time series (see Eqs. 7 and 8) are presented for five large zonal regions and for two altitude layers representing approximately the upper troposphere (UT, $8 \mathrm{~km}$ to $12 \mathrm{~km}$ ) and lower stratosphere (LS, $16 \mathrm{~km}$ to $25 \mathrm{~km}$ ). Figures 2 and 3 show the anomaly difference time series and their trends for refractivity and temperature, respectively. All trends refer to the inspected 7-yr pe- riod. To underpin the benefit of sampling error removal (see Sect. 3) we show those results before and after sampling error subtraction. The effect of removal is clearly visible in a reduced variability of the time series and a higher consistency of the anomaly differences. In the following we discuss the results after sampling error subtraction.

Good consistency of refractivity anomaly differences is found for all centers. Refractivity difference trends are within $\pm 0.03 \%$ per $7 \mathrm{yr}$ in most regions, with larger difference trends found at SML and SHL in the UT (-0.05\% to $0.03 \%)$ 

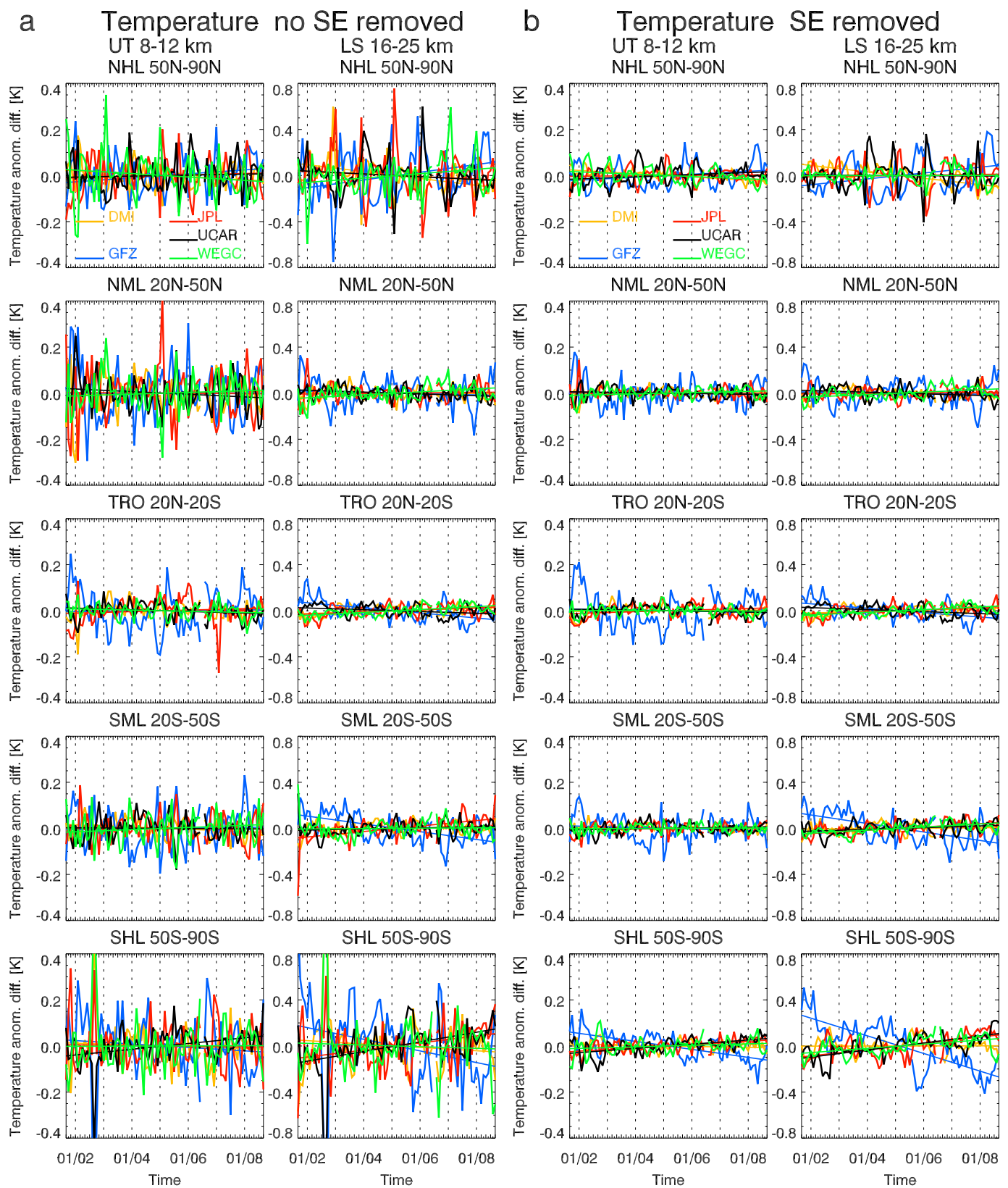

Fig. 3. De-seasonalized anomaly difference time series and trends of (a) temperature and of (b) temperature where sampling error was subtracted, shown for the (left) UT and (right) LS for (top to bottom) five zonal regions. Note the different y-axis for the UT and the LS region.

and at SHL in the LS $(-0.08 \%$ to $0.03 \%)$. Temperature anomaly difference trends are near-zero in all UT regions except at SHL being about $\pm 0.1 \mathrm{~K}$. In the LS, temperature difference trends are below $\pm 0.2 \mathrm{~K}$ in all regions except at SHL. GFZ anomaly difference time series show larger variability and larger difference trends at SML and SHL regions. Since raw bending angles do not show these differences this can be related to GFZ's approach of bending angle initialization, especially the weighting of RO measurements with re- spect to background information (see also Table 1 and further discussion in Sect. 4.3). These results indicate the advantage of the use of bending angle climatologies for climate trend studies (Ringer and Healy, 2008).

The spread of mean anomaly difference trends for the focus region $\left(50^{\circ} \mathrm{N}\right.$ to $50^{\circ} \mathrm{S}, 8 \mathrm{~km}$ to $\left.25 \mathrm{~km}\right)$ is $-0.01 \%$ to $0.03 \%$ for bending angle, $-0.02 \%$ to $0.03 \%$ for refractivity, $-0.04 \%$ to $0.04 \%$ for pressure, $-3.7 \mathrm{~m}$ to $3.0 \mathrm{~m}$ for geopotential height, and $-0.08 \mathrm{~K}$ to $0.05 \mathrm{~K}$ for temperature. 

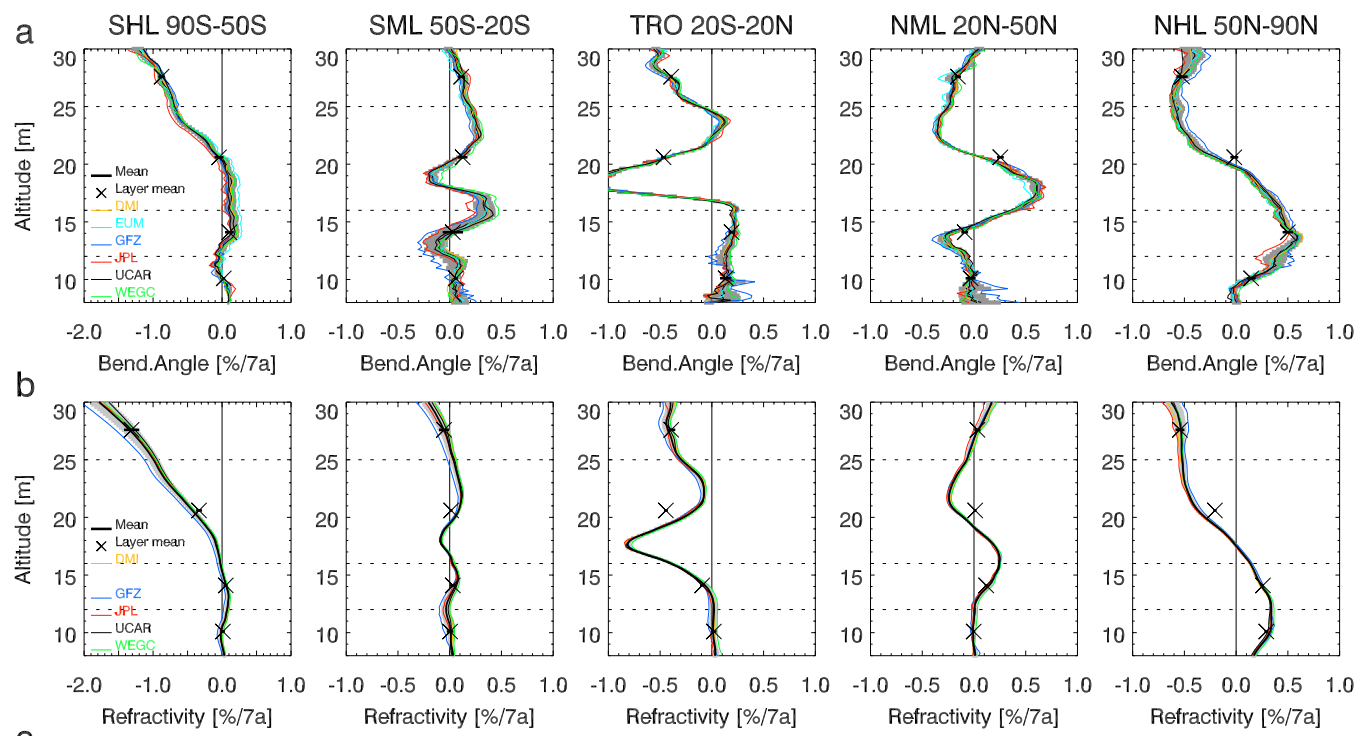

C
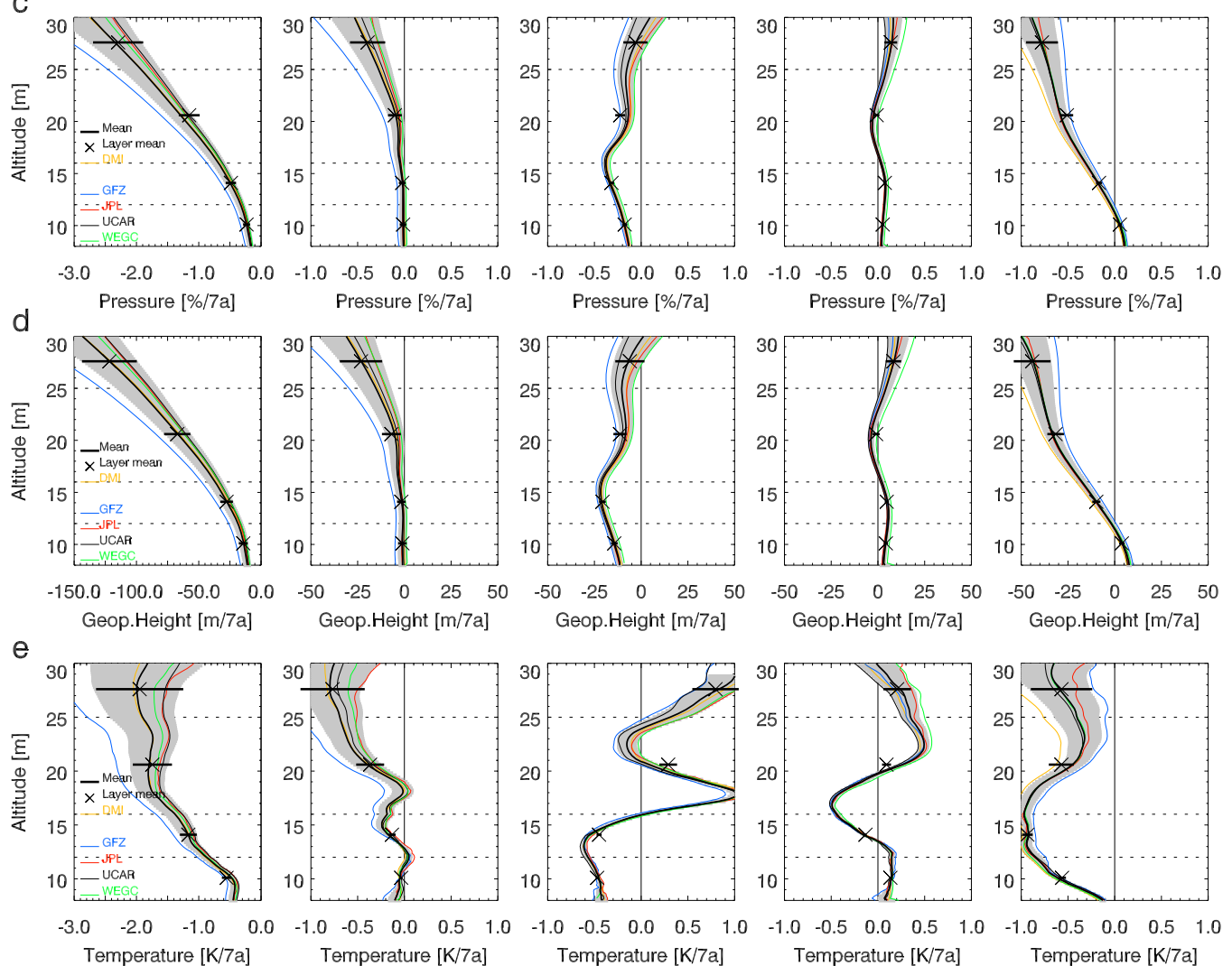

Fig. 4. Temperature trend (black line) and standard deviation (gray) of the all-center mean for the CHAMP period September 2001 to September 2008 shown for (a) bending angle, (b) refractivity, (c) pressure, (d) geopotential height, and (e) temperature for (left to right) five zonal regions. Layer mean values are indicated (crosses). Individual center trends are shown for DMI (yellow), GFZ (blue), JPL (red), UCAR (black), WEGC (green). Note the different $x$-axis for the SHL region.

The results are consistent with former refractivity uncertainty estimates (upper bound of $0.03 \%$ per $5 \mathrm{yr}$ ) of Ho et al. (2009). Furthermore, our findings are consistent with the recent estimates of the profile-by-profile data set study of
Ho et al. (2012), who showed, e.g. $\pm 0.02 \%$ per $5 \mathrm{yr}$ for refractivity uncertainty and who discussed processing causes for structural uncertainty in detail. This consistency in results from different methodologies indicates that residual 
Table 2. Mean trend (all-center mean) and standard deviation of the trend for six latitude regions and five altitude layers, for bending angle, refractivity, pressure, geopotential height, and temperature. The all-center mean includes DMI, EUM, GFZ, JPL, UCAR, WEGC for bending angle, and DMI, GFZ, JPL, UCAR, WEGC for refractivity to temperature. The estimated sampling error was subtracted for each parameter except for bending angle.

\begin{tabular}{|c|c|c|c|c|c|}
\hline \multicolumn{6}{|c|}{$\begin{array}{l}\text { All-center mean trend and standard deviation } \\
\text { Latitude }\end{array}$} \\
\hline & Bend. Angle & Refractivity & Pressure & Geop. Height & Temperature \\
\hline Altitude (km) & $(\%$ per $7 \mathrm{yr})$ & $(\%$ per $7 \mathrm{yr})$ & $(\%$ per $7 \mathrm{yr})$ & (m per $7 \mathrm{yr}$ ) & (K per 7 yr) \\
\hline \multicolumn{6}{|c|}{$50^{\circ} \mathrm{N}-50^{\circ} \mathrm{S}$} \\
\hline 8 to 25 & $0.02 \pm 0.02$ & $-0.06 \pm 0.02$ & $-0.12 \pm 0.03$ & $-7.84 \pm 2.44$ & $-0.07 \pm 0.05$ \\
\hline 8 to 12 & $0.08 \pm 0.03$ & $0.00 \pm 0.02$ & $-0.09 \pm 0.03$ & $-6.66 \pm 1.66$ & $-0.21 \pm 0.01$ \\
\hline 12 to 16 & $0.05 \pm 0.04$ & $-0.03 \pm 0.02$ & $-0.15 \pm 0.03$ & $-9.42 \pm 1.59$ & $-0.26 \pm 0.02$ \\
\hline 16 to 25 & $-0.14 \pm 0.02$ & $-0.21 \pm 0.01$ & $-0.14 \pm 0.05$ & $-7.61 \pm 3.24$ & $0.07 \pm 0.09$ \\
\hline 25 to 30 & $-0.19 \pm 0.02$ & $-0.18 \pm 0.04$ & $-0.10 \pm 0.12$ & $-7.01 \pm 7.16$ & $0.20 \pm 0.22$ \\
\hline \multicolumn{6}{|c|}{$50^{\circ} \mathrm{N}-90^{\circ} \mathrm{N}$} \\
\hline 8 to 25 & $0.21 \pm 0.04$ & $0.17 \pm 0.01$ & $-0.14 \pm 0.03$ & $-18.16 \pm 3.18$ & $-0.66 \pm 0.09$ \\
\hline 8 to 12 & $0.15 \pm 0.04$ & $0.29 \pm 0.02$ & $0.06 \pm 0.02$ & $3.83 \pm 1.44$ & $-0.56 \pm 0.04$ \\
\hline 12 to 16 & $0.50 \pm 0.05$ & $0.26 \pm 0.01$ & $-0.17 \pm 0.03$ & $-9.84 \pm 2.17$ & $-0.93 \pm 0.06$ \\
\hline 16 to 25 & $-0.02 \pm 0.04$ & $-0.21 \pm 0.02$ & $-0.51 \pm 0.07$ & $-31.62 \pm 4.44$ & $-0.57 \pm 0.13$ \\
\hline 25 to 30 & $-0.52 \pm 0.05$ & $-0.54 \pm 0.04$ & $-0.78 \pm 0.17$ & $-44.13 \pm 9.85$ & $-0.57 \pm 0.33$ \\
\hline \multicolumn{6}{|c|}{$20^{\circ} \mathrm{N}-50^{\circ} \mathrm{N}$} \\
\hline 8 to 25 & $0.03 \pm 0.02$ & $0.04 \pm 0.01$ & $0.04 \pm 0.02$ & $1.62 \pm 1.49$ & $0.04 \pm 0.03$ \\
\hline 8 to 12 & $-0.03 \pm 0.05$ & $-0.00 \pm 0.01$ & $0.05 \pm 0.02$ & $4.24 \pm 1.12$ & $0.13 \pm 0.01$ \\
\hline 12 to 16 & $-0.09 \pm 0.03$ & $0.12 \pm 0.02$ & $0.07 \pm 0.02$ & $4.73 \pm 1.07$ & $-0.13 \pm 0.01$ \\
\hline 16 to 25 & $0.26 \pm 0.03$ & $0.01 \pm 0.01$ & $-0.01 \pm 0.03$ & $-0.96 \pm 1.87$ & $0.09 \pm 0.05$ \\
\hline 25 to 30 & $-0.16 \pm 0.03$ & $0.03 \pm 0.03$ & $0.14 \pm 0.07$ & $8.32 \pm 4.14$ & $0.21 \pm 0.15$ \\
\hline \multicolumn{6}{|c|}{$20^{\circ} \mathrm{N}-20^{\circ} \mathrm{S}$} \\
\hline 8 to 25 & $-0.01 \pm 0.03$ & $-0.13 \pm 0.02$ & $-0.23 \pm 0.03$ & $-14.30 \pm 2.66$ & $-0.06 \pm 0.06$ \\
\hline 8 to 12 & $0.13 \pm 0.06$ & $0.02 \pm 0.03$ & $-0.18 \pm 0.03$ & $-14.36 \pm 1.78$ & $-0.47 \pm 0.02$ \\
\hline 12 to 16 & $0.19 \pm 0.03$ & $-0.09 \pm 0.02$ & $-0.32 \pm 0.03$ & $-20.67 \pm 1.77$ & $-0.45 \pm 0.03$ \\
\hline 16 to 25 & $-0.47 \pm 0.02$ & $-0.44 \pm 0.02$ & $-0.22 \pm 0.05$ & $-11.30 \pm 3.52$ & $0.29 \pm 0.09$ \\
\hline 25 to 30 & $-0.39 \pm 0.01$ & $-0.39 \pm 0.04$ & $-0.06 \pm 0.13$ & $-6.04 \pm 7.81$ & $0.80 \pm 0.25$ \\
\hline \multicolumn{6}{|c|}{$20^{\circ} \mathrm{S}-50^{\circ} \mathrm{S}$} \\
\hline 8 to 25 & $0.07 \pm 0.04$ & $0.01 \pm 0.03$ & $-0.04 \pm 0.04$ & $-4.28 \pm 3.72$ & $-0.23 \pm 0.09$ \\
\hline 8 to 12 & $0.06 \pm 0.02$ & $0.00 \pm 0.03$ & $-0.01 \pm 0.04$ & $-1.04 \pm 2.30$ & $-0.03 \pm 0.02$ \\
\hline 12 to 16 & $0.03 \pm 0.10$ & $0.03 \pm 0.03$ & $-0.02 \pm 0.04$ & $-1.63 \pm 2.30$ & $-0.13 \pm 0.04$ \\
\hline 16 to 25 & $0.13 \pm 0.05$ & $0.01 \pm 0.01$ & $-0.10 \pm 0.07$ & $-6.93 \pm 5.06$ & $-0.37 \pm 0.15$ \\
\hline 25 to 30 & $0.11 \pm 0.03$ & $-0.05 \pm 0.05$ & $-0.39 \pm 0.19$ & $-23.19 \pm 11.33$ & $-0.77 \pm 0.34$ \\
\hline \multicolumn{6}{|c|}{$50^{\circ} \mathrm{S}-90^{\circ} \mathrm{S}$} \\
\hline 8 to 25 & $0.03 \pm 0.04$ & $-0.05 \pm 0.03$ & $-0.51 \pm 0.09$ & $-45.39 \pm 7.61$ & $-1.33 \pm 0.22$ \\
\hline 8 to 12 & $0.02 \pm 0.02$ & $0.01 \pm 0.03$ & $-0.23 \pm 0.06$ & $-14.28 \pm 3.61$ & $-0.55 \pm 0.08$ \\
\hline 12 to 16 & $0.11 \pm 0.06$ & $0.05 \pm 0.03$ & $-0.48 \pm 0.08$ & $-27.67 \pm 5.11$ & $-1.17 \pm 0.14$ \\
\hline 16 to 25 & $-0.04 \pm 0.06$ & $-0.33 \pm 0.04$ & $-1.15 \pm 0.17$ & $-67.26 \pm 10.55$ & $-1.74 \pm 0.31$ \\
\hline 25 to 30 & $-0.88 \pm 0.05$ & $-1.31 \pm 0.11$ & $-2.29 \pm 0.40$ & $-121.72 \pm 22.05$ & $-1.95 \pm 0.70$ \\
\hline
\end{tabular}

sampling error is minor to negligible within the error budget of RO climatological products. Here we finally inspect, in the next subsection, the altitude-resolved structural uncertainty of climate fields, which is relevant for many climate applications.

\subsection{Mean trends and structural uncertainty}

All-center mean trends and their standard deviations $\sigma$ for the 7-yr period are presented in Fig. 4 for all inspected RO variables. For different timescales the given (random) uncertainties scale as $\sigma\left(\Delta t / \Delta t_{\text {target }}\right)^{3 / 2}$, where $\Delta t$ is $7 \mathrm{yr}$ and $\Delta t_{\text {target }}$ is the target time (Leroy et al., 2008) (e.g. $\sigma=3 \mathrm{~m}$ per $7 \mathrm{yr}$ translates to an error of $2.5 \mathrm{~m}$ per $10 \mathrm{yr}$ for a $10-\mathrm{yr}$ time 
series). The trends in Fig. 4 are resolved at the full altitude grid for five large zonal-mean regions. Layer-mean trends are also shown and summarized in Table 2 .

The standard deviation of bending angle trends is $<0.05 \%$ in most of the inspected regions, ranging from $0.02 \%$ in the tropics to $0.06 \%$ at SHL (note that sampling error is not subtracted for bending angle). For refractivity the standard deviation is $<0.04 \%$, becoming larger only at SHL above $25 \mathrm{~km}$. For pressure (geopotential height) trends the standard deviation is $0.03 \%$ to $0.05 \%$ ( $2 \mathrm{~m}$ to $3 \mathrm{~m}$ ) in the whole UT and the LS tropics. It increases to $0.07 \%(5 \mathrm{~m})$ at mid- and highlatitudes in the LS and is largest at SHL and above $25 \mathrm{~km}$ with $0.2 \%$ to $0.4 \%$ ( $10 \mathrm{~m}$ to $20 \mathrm{~m}$ ). The standard deviation of temperature trends in the tropics and mid-latitudes is $0.02 \mathrm{~K}$ in the UT and $0.1 \mathrm{~K}$ in the LS. At high latitudes it is $<0.1 \mathrm{~K}$ in the UT and increases to $0.3 \mathrm{~K}$ in the LS. Above $25 \mathrm{~km}$ altitude the errors range from $0.2 \mathrm{~K}$ in the tropics to $0.7 \mathrm{~K}$ at high latitudes. For completeness of information, Table 3 presents the structural uncertainty at specific altitude levels from $8 \mathrm{~km}$ to $30 \mathrm{~km}$ for every other kilometer.

Overall, structural uncertainty is lowest where the measurement information content is highest. Structural uncertainty increases with increasing altitude and at high latitudes. The larger differences between centers are regarded to mainly stem from increased sensitivity to the different bending angle initialization at high altitudes in the centers' processing schemes. Different centers use different a priori information, i.e. climatology models (DMI, GFZ, UCAR), exponential extrapolation (JPL), or numerical weather prediction forecasts (WEGC). The initialization approach affects uncertainty from about $25 \mathrm{~km}$ upwards and the atmospheric products become increasingly sensitive to a priori information as the altitude increases. Figure 4 also indicates that the centers using climatologies as background show a more exaggerated behavior of trends, e.g. larger trends of GFZ at SML and SHL, and of DMI at NHL. This is related to the limitations of the Mass Spectrometer and Incoherent Scatter radar (MSIS) climatology (Hedin, 1991) in representing the high-latitude variability in the stratosphere and mesosphere. Current efforts on improving this optimization processing step involve the use of monthly mean RO climatologies (Ao et al., 2012; Gleisner and Healy, 2013). Higher structural uncertainty at high latitudes is also caused by a larger residual sampling error (Scherllin-Pirscher et al., 2011a); at SHL the standard deviation does not decrease much after sampling error subtraction in contrast to all other regions (Fig. 4). The larger differences below $10 \mathrm{~km}$ in the tropics and midlatitudes arise probably due to differences in geometric optics and wave optics retrievals as well as differences in downward extrapolation of L1-L2 for ionospheric correction (see Sect. 2 and Table 1).

Table 2 summarizes the 7-yr trend and associated structural uncertainty values for $50^{\circ} \mathrm{N}$ to $50^{\circ} \mathrm{S}$ and the five altitude layers. The estimated uncertainty within $8 \mathrm{~km}$ to $25 \mathrm{~km}$ is $0.02 \%$ for bending angle, $0.02 \%$ for refractivity, $0.03 \%$ for pressure, $2.5 \mathrm{~m}$ for geopotential height, and $0.05 \mathrm{~K}$ for temperature.

In general, a data record suitable for climate monitoring should depict the mean state and the variability of the atmosphere with an accuracy better than the expected long-term changes. Observation requirements for satellite-based products for climate are given by the GCOS programme (GCOS, 2006; 2010). The stability requirement for air temperature as ECV is defined as $0.05 \mathrm{~K} /$ decade for the troposphere and $0.1 \mathrm{~K} /$ decade for the lower stratosphere (GCOS, 2006).

No dedicated GCOS requirements exist for the other RO variables but from physical relations between these variables reasonable scaling is possible, including $0.1 \mathrm{~K} \mathrm{decade}$ de $^{-1}$ corresponding to a requirement of about $0.05 \%$ decade $^{-1}$ in refractivity (factor $\sim 0.5$; e.g. Ho et al., 2009; Scherllin-Pirscher et al., 2011b) and further on to about $0.12 \%$ decade $^{-1}$ in bending angle (factor $\sim 2.4$; e.g. Sofieva and Kyrölä, 2004; Scherllin-Pirscher et al., 2011b). Furthermore, geopotential height change $\left(\mathrm{m} \mathrm{decade}^{-1}\right)$ relates to relative pressure change $\left(\% \mathrm{decade}^{-1}\right)$ via the atmospheric scale height by a factor of about $70 \mathrm{~m} \%^{-1}$ (e.g. Leroy et al., 2006b; Scherllin-Pirscher et al., 2011b) so that expected climate change signals in geopotential height of roughly $10 \mathrm{~m} \mathrm{decade}^{-1}$ at low to mid latitudes (Leroy et al., 2006b; Lackner et al., 2011) suggest a stability requirement like $4 \mathrm{~m} \mathrm{decade}^{-1}$, and correspondingly of $0.06 \% \mathrm{decade}^{-1}$ for pressure, to be reasonable values.

This more complete set of requirements indicates that in addition to the temperature meeting the GCOS requirements also the other $\mathrm{RO}$ variables meet related requirements within the core domain $50^{\circ} \mathrm{N}$ to $50^{\circ} \mathrm{S}$ and $8 \mathrm{~km}$ to $25 \mathrm{~km}$.

We note that the purpose of our trend analysis here is to provide an estimate of the structural uncertainty of climate trends from RO but not to interpret the trends climatologically. A thorough analysis of climate trends requires a full multivariate regression analysis also accounting for natural variability, e.g. El Niño Southern Oscillation and QuasiBiennial-Oscillation (see e.g. Steiner et al., 2009; 2011). For this study we just performed a standard linear regression for the 7-yr CHAMP data set in order to derive the uncertainty of trends but the trends themselves are not meaningful in a climatological sense.

For context, Lackner et al. (2011) showed in a dedicated climate change signal detection study for RO a geopotential height increase of $\sim 15 \mathrm{~m} \mathrm{decade}^{-1}$, a warming of $\sim 0.3 \mathrm{~K} \mathrm{decade}^{-1}$ in the UT and a cooling of a $\sim 0.6 \mathrm{~K} \mathrm{decade}^{-1}$ in the LS tropics for the period 2001 to 2010. The corresponding structural uncertainty in the tropics as found from this uncertainty study is for geopotential height $<3 \mathrm{~m} \mathrm{decade}^{-1}$ in the UTLS. For temperature it is $0.02 \mathrm{~K} \mathrm{decade}^{-1}$ in the UT and $0.07 \mathrm{~K} \mathrm{decade}^{-1}$ in the LS, which meets GCOS stability requirements for air temperature and allows for a detection of the above trends as found by Lackner et al. (2011). 
Table 3. Mean trend (all-center mean) and standard deviation of the trend for altitude levels from $8 \mathrm{~km}$ to $30 \mathrm{~km}$ at every other kilometer and for five latitude regions, for bending angle $(\alpha)$, refractivity $(N)$, pressure $(p)$, geopotential height $(Z)$, and temperature $(T)$. The all-center mean includes DMI, EUM, GFZ, JPL, UCAR, WEGC for bending angle, and DMI, GFZ, JPL, UCAR, WEGC for refractivity to temperature. The estimated sampling error was subtracted for each parameter except for bending angle.

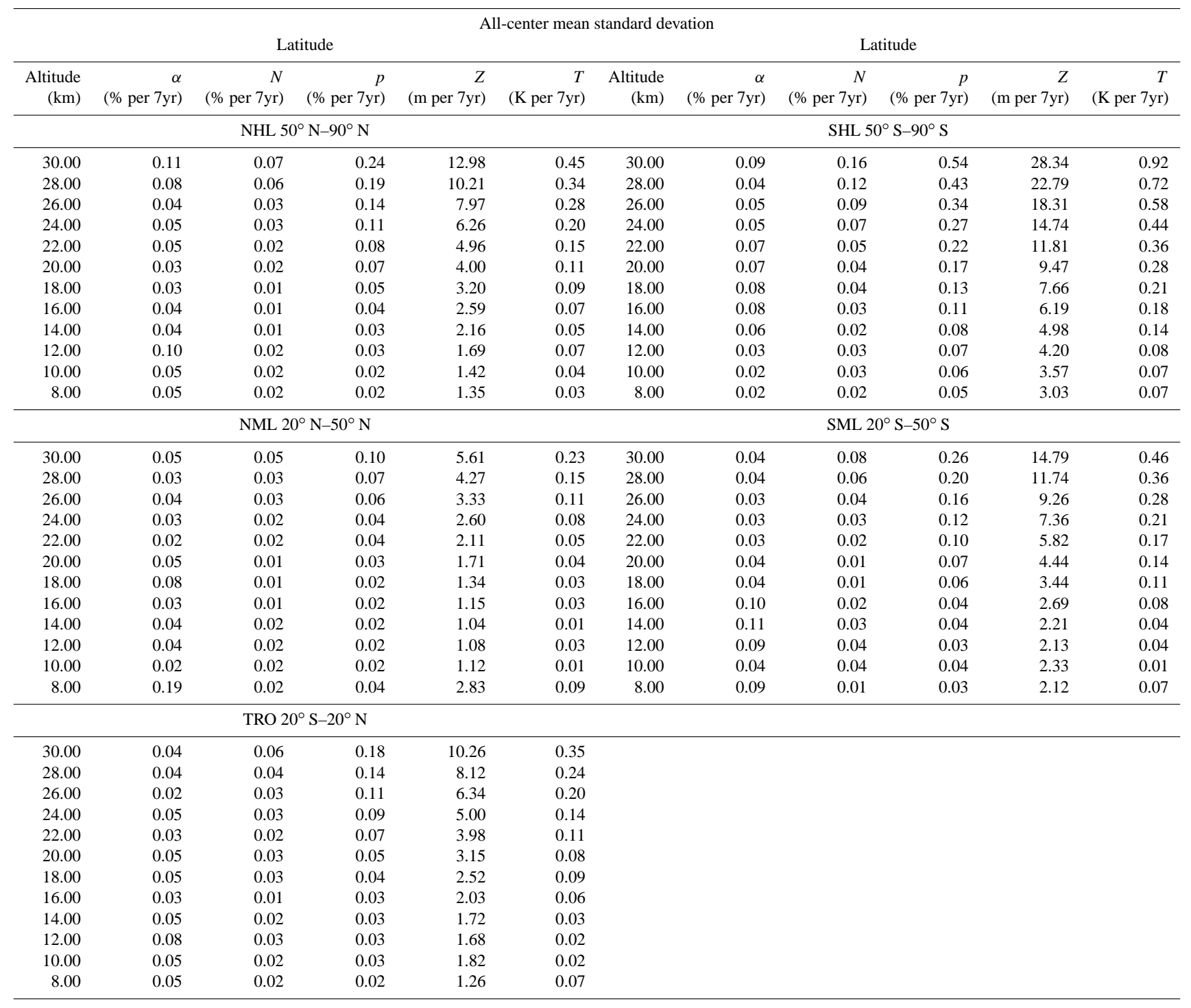

We also note the very high vertical resolution of RO data, which becomes most obvious near the tropical tropopause and is an important feature for resolving the vertical structure of atmospheric trends, filling a current lack of information in atmospheric trend studies in the UTLS.

\section{Summary and conclusions}

We quantified the structural uncertainty in trends based on RO climate records from six international RO processing centers for the full set of RO atmospheric variables, including bending angle, refractivity, dry pressure, dry geopotential height, and dry temperature. RO profile data from the CHAMP mission were delivered by DMI Copenhagen, EUM Darmstadt, GFZ Potsdam, JPL Pasadena, UCAR Boulder, and WEGC Graz. Monthly-mean zonal-mean climatological fields were computed for the period September 2001 to September 2008. The sampling error due to discrete sampling in space and time was estimated and subtracted. Anomaly difference time series with respect to the all-center mean were analyzed for assessing deviations between the data sets due to different processing methods. The spread of anomaly difference trends and finally the standard deviation of the all-center mean trend were used as an estimate of the structural uncertainty. 
We showed that RO structural uncertainty from different processing schemes is lowest in the tropics and mid-latitudes at $8 \mathrm{~km}$ to $25 \mathrm{~km}$ for all inspected $\mathrm{RO}$ variables. The resulting mean standard deviation of trends is $0.02 \%$ per $7 \mathrm{yr}$ for bending angle, $0.02 \%$ for refractivity, $0.03 \%$ for pressure, $<3 \mathrm{~m}$ for geopotential height, and $0.05 \mathrm{~K}$ for temperature. Structural uncertainty increases above $25 \mathrm{~km}$ and at high latitudes, mainly due to increased sensitivity to the different bending angle initialization approaches implemented at each center including different high altitude background information. At high latitudes larger residual sampling error due to higher atmospheric variability is also a factor.

These results based on monthly-mean climatologies were found to be consistent with the results of a complementary profile-based intercomparison study, indicating that residual sampling error is generally negligible and underlining the value of RO climatological products. The consistency of findings from the different studies, based on different data versions and methodological approaches, further underpins the quality of RO data and their utility for climate studies.

In conclusion, the quantification of structural uncertainty completes the error characterization of current data sets as summarized by Steiner et al. (2011). Currently GPS RO can be used for climate trend assessments within the region from $50^{\circ} \mathrm{S}$ to $50^{\circ} \mathrm{N}$ and below $25 \mathrm{~km}$ altitude, where structural uncertainty meets stability requirements for air temperature as defined by GCOS as well as corresponding requirements for the other RO variables. Since RO processing systems undergo continuous development, further improvements can be expected, enlarging the latitude and altitude range of low uncertainty. Overall, our assessment shows that quality, consistency, and reproducibility of the data are favorable for the establishment of a climate benchmark record.

Acknowledgements. We thank ECMWF Reading for access to their atmospheric re-analysis data. The DMI work was supported by the Radio Occultation Meteorology Satellite Application Facility (ROM SAF, formerly GRAS SAF) which is an operational RO processing center under EUMETSAT. DMI thanks K. R. Larsen for assistance in the processing of data. The work of EUM was partially funded by the ERA-CLIM project, under the Seventh Framework Programme for Research and Technological Development of the European Commission (FP7). The work of GFZ was supported by GEOTECHNOLOGIEN grant 03G0728A. The work of JPL, California Institute of Technology, was carried out under a contract with the National Aeronautics and Space Administration. The work of UCAR was supported by the National Science Foundation under Cooperative Agreement No. AGS-0918398/CSA No. AGS0939962. The work of WEGC was funded by the Austrian Science Fund (FWF) grants P21642-N21 and P22293-N21 and partially by European Space Agency and FFG-ALR Austria contracts.

Edited by: G. Stiller

\section{References}

Anthes, R. A.: Exploring Earth's atmosphere with radio occultation: contributions to weather, climate and space weather, Atmos. Meas. Tech., 4, 1077-1103, doi:10.5194/amt-4-1077-2011, 2011.

Ao, C. O., Mannucci, A. J., and Kursinski, E. R.: Improving GPS radio occultation stratospheric refractivity for climate benchmarking, Geophys. Res. Lett., 39, L12701, doi:10.1029/2012GL051720, 2012.

Bertiger, W. I., Bar-Sever, Y. E., Christensen, E. J., Davis, E. S., Guinn, J. R., Haines, B. J., Ibanez-Meier, R. W., Jee, J. R., Lichten, S. M., Melbourne, W. G., Muellerschoen, R. J., Munson, T. N., Vigue, Y., Wu, S. C., Yunck, T. P., Schutz, B. E., Abusali, P. A. M., Rim, H. J., Watkins, M. M., and Willis, P.: GPS precise tracking of TOPEX/Poseidon: Results and implications, J. Geophys. Res., 99, 24449-24464, doi:10.1029/94JC01171, 1994.

Dach, R., Hugentobler, U., Fridez, P., and Meindl, M. (Eds.): User Manual of the Bernese GPS Software Version 5.0, Astron. Inst., Univ. of Bern, Bern, Switzerland, 2007.

Dee, D. P., Uppala, S. M., Simmons, A. J., Berrisford, P., Poli, P., Kobayashi, S., Andrae, U., Balmaseda, M. A., Balsamo, G., Bauer, P., Bechtold, P., Beljaars, A. C. M., van de Berg, L., Bidlot, J., Bormann, N., Delsol, C., Dragani, R., Fuentes, M., Geer, A. J., Haimberger, L., Healy, S. B., Hersbach, H., Hólm, E. V., Isaksen, L., Kållberg, P., Köhler, M., Matricardi, M., McNally, A. P., Monge-Sanz, B. M., Morcrette, J.-J., Park, B.-K., Peubey, C., de Rosnay, P., Tavolato, C., Thépaut, J.-N., and Vitart, F.: The ERA-Interim reanalysis: configuration and performance of the data assimilation system, Q. J. Roy. Meteor. Soc., 137, 553-597, doi:10.1002/qj.828, 2011.

Fjeldbo, G., Kliore, A. J., and Eshleman, V.: The neutral atmosphere of Venus as studied with Mariner V radio occultation experiments, Astron. J., 76, 123-140, doi:10.1086/111096, 1971.

Foelsche, U., Borsche, M., Steiner, A. K., Gobiet, A., Pirscher, B., Kirchengast, G., Wickert, J., and Schmidt, T.: Observing upper troposphere-lower stratosphere climate with radio occultation data from the CHAMP satellite, Clim. Dynam., 31, 49-65, doi:10.1007/s00382-007-0337-7, 2008.

Foelsche, U., Scherllin-Pirscher, B., Ladstädter, F., Steiner, A. K., and Kirchengast, G.: Refractivity and temperature climate records from multiple radio occultation satellites consistent within 0.05\%, Atmos. Meas. Tech., 4, 2007-2018, doi:10.5194/amt-4-2007-2011, 2011.

GCOS: Systematic observation requirements for satellite-based products for climate, GCOS-107 (WMO/TD No. 1338), 2006.

GCOS: Guidelines for the generation of datasets and products meeting GCOS requirements, GCOS-143, 2010.

Gleisner, H. and Healy, S. B.: A simplified approach for generating GNSS radio occultation refractivity climatologies, Atmos. Meas. Tech., 6, 121-129, doi:10.5194/amt-6-121-2013, 2013.

Gobiet, A. and Kirchengast, G.: Advancements of GNSS radio occultation retrieval in the upper stratosphere for optimal climate monitoring utility, J. Geophys. Res., 109, D24110, doi:10.1029/2004JD005117, 2004.

Gobiet, A., Kirchengast, G., Manney, G. L., Borsche, M., Retscher, C., and Stiller, G.: Retrieval of temperature profiles from CHAMP for climate monitoring: intercomparison with Envisat MIPAS and GOMOS and different analyses, Atmos. Chem. Phys., 7, 3519-3536, doi:10.5194/acp-7-3519-2007, 2007. 
Gorbunov, M. E.: Canonical transform method for processing radio occultation data in the lower troposphere, Radio Sci., 37, 1076, doi:10.1029/2000RS002592, 2002.

Gorbunov, M. E. and Lauritsen, K. B.: Analysis of wave fields by Fourier integral operators and their application for radio occultations, Radio Sci., 39, RS4010, doi:10.1029/2003RS002971, 2004.

Hajj, G. A., Kursinski, E. R., Romans, L. J., Bertiger, W. I., and Leroy, S. S.: A technical description of atmospheric sounding by GPS occultation, J. Atmos. Sol.-Terr. Phys., 64, 451-469, doi:10.1016/S1364-6826(01)00114-6, 2002.

Hajj, G. A., Ao, C. O., Iijima, B. A., Kuang, D., Kursinski, E. R., Mannucci, A. J., Meehan, T. K., Romans, L. J., de la Torre Juarez, M., and Yunck, T. P.: CHAMP and SAC-C atmospheric occultation results and intercomparisons, J. Geophys. Res., 109, D23107, doi:10.1029/2003JD003909, 2004.

Healy, S. B.: Smoothing radio occultation bending angles above 40 km, Ann. Geophys., 19, 459-468, doi:10.5194/angeo-19-4592001, 2001.

Hedin, A. E.: Extension of the MSIS thermosphere model into the middle and lower atmosphere, J. Geophys. Res., 96, 1159-1172, doi:10.1029/90JA02125, 1991.

Ho, S.-P., Kirchengast, G., Leroy, S., Wickert, J., Mannucci, T., Steiner, A. K., Hunt, D., Schreiner, W., Sokolovskiy, S. V., Ao, C. O., Borsche, M., von Engeln, A., Foelsche, U., Heise, S., Iijima, B., Kuo, Y.-H., Kursinski, E. R., Pirscher, B., Ringer, M., Rocken, C., and Schmidt, T.: Estimating the uncertainty of using GPS radio occultation data for climate monitoring: Intercomparison of CHAMP refractivity climate records from 2002 to 2006 from different data centers, J. Geophys. Res., 114, D23107, doi:10.1029/2009JD011969, 2009.

Ho, S.-P., Hunt, D., Steiner, A. K., Mannucci, A., Kirchengast, G., Gleisner, H., Heise, S., von Engeln, A., Marquardt, C., Sokolovskiy, S., Schreiner, W., Scherllin-Pirscher, B., Ao, C., Wickert, J., Syndergaard, S., Lauritsen, K., Leroy, S., Kursinski, E. R., Kuo, Y.-H., Foelsche, U., Schmidt, T., and Gorbunov, M.: Reproducibility of GPS radio occultation data for climate monitoring: Profile-to-profile inter-comparison of CHAMP climate records 2002 to 2008 from six data centers, J. Geophys. Res., 117, D18111, doi:10.1029/2012JD017665, 2012.

Hoaglin, D. C., Mosteller, F., and Tukey, J. W. (Eds.): Understanding Robust and Exploratory Data Analysis, Wiley, New York, USA, 1983.

Immler, F. J., Dykema, J., Gardiner, T., Whiteman, D. N., Thorne, P. W., and Vömel, H.: Reference Quality Upper-Air Measurements: guidance for developing GRUAN data products, Atmos. Meas. Tech., 3, 1217-1231, doi:10.5194/amt-3-1217-2010, 2010.

Jensen, A. S., Lohmann, M., Benzon, H.-H., and Nielsen, A.: Full spectrum inversion of radio occultation signals, Radio Sci., 38, 1040, doi:10.1029/2002RS002763, 2003.

Karl, T. R., Hassol, S. J., Miller, C. D., and Murray, W. L. (Eds.): Temperature Trends in the Lower Atmosphere: Steps for Understanding and Reconciling Differences, A Report by the Climate Change Science Program and the Subcommittee on Global Change Research, Washington, DC, 2006.

König, R., Michalak, G., Neumayer, K., and Zhu, S.: Remarks on CHAMP orbit products, in: Observation of the Earth System From Space, edited by: Flury, J., Rummel, R., Reigber, C., Rothacher, M., Boedecker, G., and Schreiber, U., Springer,
Berlin, Germany, 17-26, 2006.

Kursinski, E. R., Hajj, G. A., Schofield, J. T., Linfield, R. P., and Hardy, K. R.: Observing Earth's atmosphere with radio occultation measurements using the Global Positioning System, J. Geophys. Res., 102, 23429-23465, doi:10.1029/97JD01569, 1997.

Lackner, B. C., Steiner, A. K., Hegerl, G. C., and Kirchengast, G.: Atmospheric climate change detection by radio occultation data using a fingerprinting method, J. Climate, 24, 5275-5291, doi:10.1175/2011JCLI3966.1, 2011.

Lauritsen K. B., Syndergaard, S., Gleisner, H., Gorbunov, M. E., Rubek, F., Sørensen, M. B., and Wilhelmsen, H.: Processing and validation of refractivity from GRAS radio occultation data, Atmos. Meas. Tech., 4, 2065-2071, doi:10.5194/amt-4-2065-2011, 2011.

Leroy, S. S., Dykema, J. A., and Anderson, J. G.: Climate benchmarking using GNSS occultation, in: Atmosphere and Climate: Studies by Occultation Methods, edited by: Foelsche, U., Kirchengast, G., and Steiner, A., Springer-Verlag, Berlin, Heidelberg, doi:10.1007/3-540-34121-8_24, 287-301, 2006a.

Leroy, S. S., Anderson, J. G., and Dykema, J. A.: Testing climate models using GPS radio occultation: a sensitivity analysis, J. Geophys. Res., 111, D17105, doi:10.1029/2005JD006145, 2006b.

Leroy, S. S., Anderson, J. G., and Ohring, G.: Climate signal detection times and constraints on climate benchmark accuracy requirements, J. Climate, 21, 841-846, doi:10.1175/2007JCLI1946.1, 2008.

Lohmann, M.: Application of dynamical error estimation for statistical optimization of radio occultation bending angles, Radio Sci., 40, RS3011, doi:10.1029/2004RS003117, 2005.

Mannucci, A. J., Ao, C., Yunck, T. P., Young, L. E., Hajj, G. A., Iijima, B. A., Kuang, D., Meehan, T. K., and Leroy, S. S.: Generating climate benchmark atmospheric soundings using GPS occultation data, Proc. SPIE, 6301, 8, doi:10.1117/12.683973, 2006.

Ohring, G. (Ed.): Achieving Satellite Instrument Calibration for Climate Change, National Oceanic and Atmospheric Administration, Washington, DC, 2007.

Poli, P., Healy, S., and Dee, D.: Assimilation of Global Positioning System radio occultation data in the ECMWF ERA-Interim reanalysis, Q. J. Roy. Meteor. Soc., 136, 1972-1990, 2010.

Randel, W. J., Shine, K. P., Austin, J., Barnett, J., Claud, C., Gillett, N. P., Keckhut, P., Langematz, U., Lin, R., Long, C., Mears, C., Miller, A., Nash, J., Seidel, D. J., Thompson, D. W. J., Wu, F., and Yoden, S.: An update of observed stratospheric temperature trends, J. Geophys. Res., 114, D02107, doi:10.1029/2008JD010421, 2009.

Ringer, M. A. and Healy, S. B.: Monitoring twenty-first century climate using GPS radio occultation bending angles, Geophys. Res. Lett., 35, L05708, doi:10.1029/2007GL032462, 2008.

Scherllin-Pirscher, B., Kirchengast G., Steiner, A. K., Kuo, Y.H., and Foelsche, U.: Quantifying uncertainty in climatological fields from GPS radio occultation: an empirical-analytical error model, Atmos. Meas. Tech., 4, 2019-2034, doi:10.5194/amt-42019-2011, 2011a.

Scherllin-Pirscher, B., Steiner A. K., Kirchengast, G., Kuo, Y.-H., and Foelsche, U.: Empirical analysis and modeling of errors of atmospheric profiles from GPS radio occultation, Atmos. Meas. Tech., 4, 1875-1890, doi:10.5194/amt-4-1875-2011, 2011 b. 
Schreiner, W., Rocken, C., Sokolovskiy, S., Syndergaard, S., and Hunt, D.: Estimates of the precision of GPS radio occultations from the COSMIC/FORMOSAT-3 mission, Geophys. Res. Lett., 34, L04808, doi:10.1029/2006GL027557, 2007.

Schreiner, W., Rocken, C., Sokolovskiy, S., and Hunt, D.: Quality assessment of COSMIC/FORMOSAT-3 GPS radio occultation data derived from single- and double-difference atmospheric excess phase processing, GPS. Solut., 14, 13-22, doi:10.1007/s10291-009-0132-5, 2010.

Smith, E. K and Weintraub, S.: The constants in the equation for atmospheric refractive Index at radio frequencies, P. Ire., 41, 10351037, doi:10.1109/JRPROC.1953.274297, 1953.

Sokolovskiy, S. and Hunt, D.: Statistical optimization approach for GPS/MET data inversion, paper presented at the URSI GPS/MET Workshop, Univ. of Ariz., Tucson, 1996,.

Sokolovskiy, S., Kuo, Y.-H., and Wang, W.: Assessing the accuracy of a linearized observation operator for assimilation of radio occultation data: Case simulations with a highresolution weather model, Mon. Weather Rev., 133, 2200-2212, doi:10.1175/MWR2948.1, 2005.

Sokolovskiy, S., Schreiner, W., Rocken, C., and Hunt, D.: Optimal noise filtering for the ionospheric correction of GPS radio occultation signals, J. Atmos. Ocean. Tech., 26, 1398-1403, doi:10.1175/2009JTECHA1192.1, 2009.

Steiner, A. K., Kirchengast, G., Lackner, B. C., Pirscher, B., Borsche, M., and Foelsche, U.: Atmospheric temperature change detection with GPS radio occultation 1995 to 2008, Geophys. Res. Lett., 36, L18702, doi:10.1029/2009GL039777, 2009.

Steiner, A. K., Lackner, B. C., Ladstädter, F., Scherllin-Pirscher, B., Foelsche, U., and Kirchengast, G.: GPS radio occultation for climate monitoring and change detection, Radio Sci., 46, RSOD24, doi:10.1029/2010RS004614, 2011.

Sofieva, V. F. and Kyrölä, E.: Abel integral inversion in occultation measurements, in: Occultations for Probing Atmosphere and Climate, edited by: Kirchengast, G., Foelsche, U., and Steiner, A. K., Springer-Verlag, Berlin, Heidelberg, 77-86, 2004.
Syndergaard, S.: Modeling the impact of the Earth's oblateness on the retrieval of temperature and pressure profiles from limb sounding, J. Atmos. Sol.-Terr. Phys., 60, 171-180, 1998.

Thorne, P. W., Parker, D. E., Christy, J. R., and Mears, C. A.: Uncertainties in climate trends: Lessons from upper-air temperature records, Bull. Am. Meteorol. Soc., 86, 1437-1442, doi:10.1175/BAMS-86-10-1437, 2005.

Thorne, P. W., Lanzante, J. R., Peterson, T. C., Seidel, D. J., and Shine, K. P.: Tropospheric temperature trends: history of an ongoing controversy, WIREs Clim. Change, 2, 66-88, doi:10.1002/wcc.80, 2011.

Trenberth, K., Trenberth, K. E, Jones, P. D., Ambenje, P., Bojariu, R., Easterling, D., Klein Tank, A., Parker, D., Rahimzadeh, F., Renwick, J. A., Rusticucci, M., Soden, B., and Zhai, P.: Observations: Surface and Atmospheric Climate Change, in: The physical science basis. Contribution of Working Group I to the fourth assessment report of the Intergovernmental Panel on Climate Change, edited by: Solomon, S., Cambridge University Press, Cambridge, 235-336, 2007.

Vorobév, V. V. and Krasil'nikova, T. G.: Estimation of the accuracy of the atmospheric refractive index recovery from Doppler shift measurements at frequencies used in the NAVSTAR system, Phys. Atmos. Ocean, 29, 602-609, 1994.

Wickert, J., Schmidt, T., Beyerle, G., König, R., Reigber, C., and Jakowski, N.: The Radio Occultation Experiment aboard CHAMP: operational data analysis and validation of vertical atmospheric profiles, J. Meteorol. Soc. Jpn., 82, 381-395, doi:10.2151/jmsj.2004.381, 2004.

Wigley, T. M. L.: Statistical Issues Regarding Trends, in: Temperature Trends in the Lower Atmosphere: Steps for Understanding and Reconciling Differences, A Report by the Climate Change Science Program and the Subcommittee on Global Change Research, edited by: Karl, T. R., Hassol, S. J., Miller, C. D., and Murray, W. L., Washington, DC, 2006. 